原 著論文

\title{
下顎片側遊離端義歯における浮上回転軸の検索
}

湊修 河野 正司

\section{Axis of Rotation Related to Vertical Displacement of a Lower Unilateral Distal Extension Removable Partial Denture}

\author{
Minato Osamu and Kohno Shoji
}

\section{歯科補経学的意義}

下顎片側遊離端義歯では，欠損部後方に支台歯がないため，義歯の安定が難しく，舌下部を通した大連結子を用い て反对側に間接支台装置を設定したりするなど，さまざまな設計が考えられている．しかし，これらの義歯構成要 素が, いかに機能しているかについての科学的な裹付けは, 現在非常に不足している. したがって, これらの義歯 構成要素の義歯動摇に対する効果と機能を明らかにすることは，補緅臨床において大きな福音となる。

抄 録

目的：義歯の構成要素を分離・交換可能な形態とし，同一条件下で繰り返し実験ができるような下顎片 側遊離端義歯を用いて，間接支台装置の形態およびレストの設定位置が，義歯床後縁の浮上にどのよう な影響を及ほすすのか検討することを目的とした。

方法：被験者の下顎運動と義歯の動摇を同期して測定するため，上鿓歯列および下顎歯列上に測定用 マーカーを設置するとともに，下䫟片側遊離端義歯にも測定用マーカーをそれぞれ口唇前方に設置し， これら 3 種のマーカーの運動を多標点運動測定装置 TMJAWGRAPH ${ }^{\circledR}$ (BTS, Italy）により同時計 測した.

結果 : 間接支台装置の形態によって，義歯床後縁点における浮上量に違いが認められた。また，間接支 台装置のレストの設定位置によって, 義歯床後縁点の浮上量に違いが認められ, 間接支台装置のレスト の設定位置が歯列後方に変化するに従って，義歯後縁点における浮上量が増加する結果が得られた。

結論：開口時における下顎片側遊離端義歯の浮上は，義歯全体の上方への並進運動による浮上と，義歯 の回転によって生じる浮上が複合したものであることが明らかとなった．義歯の回転による浮上の中心 となっている回転軸は，銁間線とは関係なく，今回の片側遊離端義歯では小歯部であった. しかし， 欠損形態や支台装置形態などによって，浮上時の回転軸は変化すると考えられる.

\section{和文キーワード}

下澦片側遊離端義歯，浮上量，鉤間線，回転軸

新潟大学大学院医歯学総合研究科捸食機能再建学分野 (主任：河野正司教授)

Division of Removable Prosthodontics, Niigata University School of Medical and Dental Sciences (Chief : Prof. Kohno Shoji)

受付: 2002 年 3 月 4 日/受理 : 2002 年 6 月 19 日

Received on March 4, 2002/Accepted on June 19, 2002 


\section{I. 緒 言}

最近の歯科保健関係統計資料1 によれば，高齢者に おける要総義歯患者数は減少傾向にあるものの, 部分 床義歯補綴を要する欠損歯列患者数は増加傾向を示し ている。これらの患者においては，欠損歯列を部分床 義歯で補緅することにより，摂食機能が著しく改善さ れ，また高齢患者においては QOL も大きく向上する ことが報告されている2,3).

しかし, 部分床義歯が咀嚼機能時に動摇すると, 支 台歯の歯周組織に為害作用を及ぼすのみでなく, 食渣 の義歯床下への迷入を招き, 円滑な咀嚼運動を阻害す るなど4,5), 補緅治療の予後を大きく左右する原因と なっている。この義歯の動摇は, 種々の要因によって 生じており，機能時の義歯動摇の様相も非常に複雑で ある。

これまでの義歯の動摇に関する研究は, 咬合時, す なわち静力学的な状態における動摇が主な対象であ $\eta^{6 \sim 9)}$ ，開口時や閉口時といった動力学的な状態にお いて，義歯がいかなる挙動を示しているかは不明な点 が多い。

そこでわれわれは，これまでに機能時に義歯の動摇 が生じやすいと考えられる下顎片側遊離端義歯を対象 として, 咀嚼時の下顎運動と義歯の動摇について, そ れぞれ 6 自由度にて同時記録・解析できるシステムを 開発し ${ }^{10)}$, 咀嚼時の義歯の動きを測定することで, 義 歯床後縁の浮上量の様相を追求してきた ${ }^{111}$. しかし, これまでの実験は, 義歯のリンガルバーを切断するな ぞ不可逆的な変化を加えて行ったため, 繰り返し実験 を行うことが不可能であるという欠点をもっていた ${ }^{11)}$. 本研究では, 上記の研究をさらに発展させて, 義歯 の構成要素を分離・交換可能な形態とし, 同一条件下 で繰り返し実験ができるような下顎片側遊離端義歯を 作製した。この義歯を使用して，間接支台装置の形態 およびレストの設定位置が, 義歯床後縁の浮上量にど のような影響を及ぼすのか検討することを目的とした。

\section{II. 実験方法}

\section{1. 被験者}

被験者は, 新潟大学歯学部附属病院補綴科を受診し
た，年齢 72 歳および 55 歳の男性ボランティア 2 名 と, 年齢 52 歳の女性ボランティア 1 名である.それ ぞれの被験者には, 本研究の主旨および内容を十分に 説明し，協力を得た。

被験者の欠損部位は，すべて下顎右側の第二小臼 歯, 第一大臼歯および第二大臼歯の下顎片側遊離端久 損症例で，Kennedy 分類II級である.

\section{2. 測定装置}

1）測定装置の概要

下顎運動および義歯の動摇の測定には, 多標点運動 測定装置 TMJAWGRAPH ${ }^{\circledR}$ (BTS, Italy) ${ }^{12,13)}$ を用 いた。

TMJAWGRAPH ${ }^{\circledR}$ の測定原理は, 測定対象の表面 に貼付した複数の赤外線反射球に赤外線を照射し，そ の反射光を離れて設置した 2 台の二次元 CCD カメラ でとらえ, 次いでサンプリングレート $50 \mathrm{~Hz}$ にて赤 外線反射球の三次元位置を測定し, 解析するシステム である ${ }^{10)}$.

本研究では, 被験者の下顎運動と義歯の動摇を同期 して測定するため, 上顎歯列および下顎歯列上に測定 用マーカーを設置するとともに，下顎片側遊離端義歯 にも測定用マーカーをそれぞれ口唇前方に設置した (図 1).

2）測定マーカー

下顎運動と義歯の動摇を同期して記録・分析するた めには, 頭部, 下顎, 義歯の動きをそれぞれ 6 自由度 で測定する ${ }^{14}$ 必要がある。そこで，各頂点に直径 3 $\mathrm{mm}$ の赤外線反射球を配置した 4 点三角錐型の測定用 マーカーを製作し，これを測定標点とすることによっ て, 下顎運動と義歯の動摇の 6 自由度測定を可能とした. 各マーカーは $0.7 \mathrm{~mm}$ のピアノ線を用いて製作し, $1.5 \mathrm{~mm}$ のピアノ線にて即時重合レジンとシアノアク リレート系の接着剤にて固定した。

製作したマーカーの全重量は上顎用で $3 \mathrm{~g}$, 下顎お よび義歯用で $2 \mathrm{~g}$ であった.

3）下顎運動および義歯の動摇解析

下顎運動および義歯の動摇解析には，土田らの開発 した ${ }^{10)}$ 専用のプログラムを使用した。

4）測定精度

座標変換後におけるマーカー上の赤外線反射球の位 置分解能は，前後方向で $0.3 \mathrm{~mm}$ 以下，左右および上 


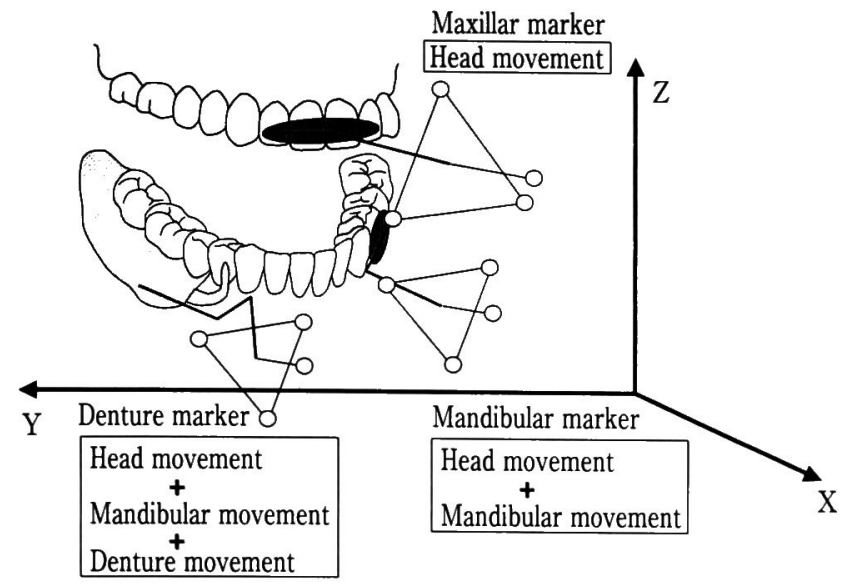

図 1 Movements in measured by each marker Marker in the upper incisors: Head movement, Marker in the lower incisors: Head movement and mandibular movement, Marker in the lower denture: Head, mandibular and denture movement

各マーカーにより測定される大地系に対する運動 上顎マーカー: 頭部運動, 下顎マーカー: 頭部運 動十下顎運動, 義歯マーカー：頭部運動十下顎運 動十義歯の動摇

下方向で $0.2 \mathrm{~mm}$ 以下である.

\section{3. 実験義歯}

実験義歯は，義歯の床形態および咬合関係を変え ず, 支台装置の形態のみを恋化させるため, 支台装置 の構成要素を分離，交換可能となるように製作し，実 験の過程で下記に示す義歯形態がとれるようにした (図 2).

支台装置分割部における接合は，雄部と雌部からな るアタッチメント形態として，接合部の固定には直径 $1 \mathrm{~mm}$ のボルト・ナットを用いた。

直接支台装置には RPI（rest proximal plate Ibar）を用いた。隣接面板は Kratochvil 型とした.

\section{4. 義歯形態}

本研究において, 下記の 2 つの実験を行った。 実験 1 では間接支台装置の形態を変化させた。すな わち, 間接支台装置に次の 3 種の形態を付与し, 義歯 床後縁の上下方向の浮上量を評価した（図 3).

形態 I：間接支台装置にレスト付二腕銁を付与.

形態II：間接支台装置に鉤腕をもたない. 形態III：間接支台装置をもたない形態.

実験 2 では間接支台装置として，鉤腕をもたないレ

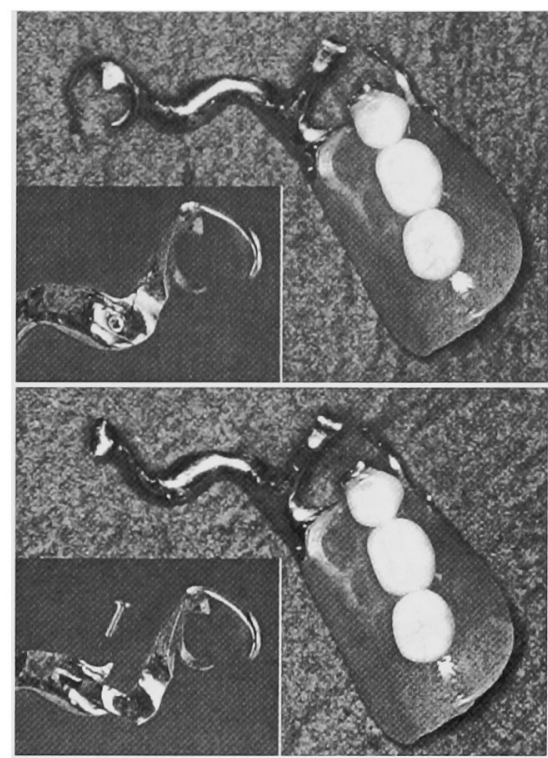

図 2 Experimental denture Indirect retainer can separate from minor connector 実験義歯 間接支台装置は小連結子部分て 交換可能

ストのみの形態を用いて，その設定位置を変化させ た.すなわち，間接支台装置のレストの設定位置を被

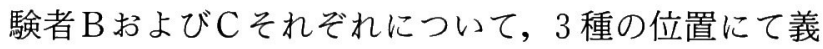
歯床後縁の上下方向の浮上量を評価した（図 3).

\section{5. 測定方法}

1）測定状態

実験に先立ち，各被験者に扔いて義歯を調整し，被 験者 $\mathrm{A}$ では形態 $\mathrm{I}$, 被験者 $\mathrm{B}, \mathrm{C}$ では形態 $\mathrm{P} 1$ の義歯 を日常生活で 2 週間使用してもらい，実験義歯によっ て十分な咀嚼機能が営める状態であることを確認し た。

測定は被験者の頭部を拘束せず，座位の楽な姿勢で 行った.

2）被験食品と被験運動

被験食品はグリーンガム ${ }^{\circledR}$ (ロッテ，東京）として， 測定前に十分軟化した状態で用いた。測定はガムを舌 の上にのせた状態で咬頭嵌合位の状態を保ち, 静止し た状態から義歯側での咀嚼を 20 秒間行わせた。

\section{3) 解析点}

義歯の動摇は三次元的に複雑な様相を示しているこ とが想像できる．そこで，歯槽頂上の義歯床後縁点， 直接支台装置のレスト，間接支台装置のレストの 3 点 


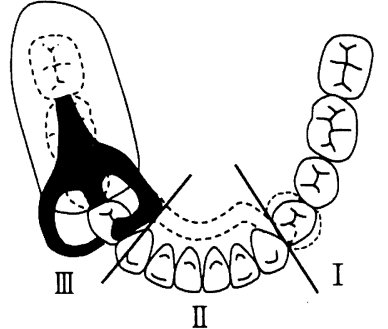

Study 1 (Sub. A)

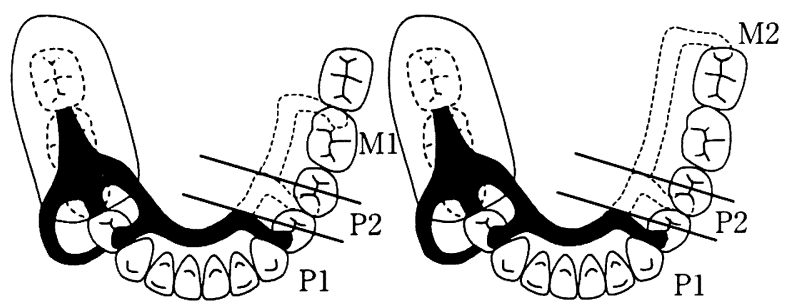

Study 2 (Sub. B)

図 3 Study 1 : Indirect retainer designs (Sub. A)

I : Conventional design, II : Only rest, III : Without indirect retainer

Study 2 : Indirect retainer positions (Sub. B)

P 1 : First premolar, P 2 : Second premolar, M 1 :

First molar

Study 2 : Indirect retainer positions (Sub. C)

P 1: First premolar, P 2: Second premolar, M 2:

Second molar

実験 1 : 間接支台装置の形態を変化させた（被験者 $\mathrm{A}$ ） I : 間接支台装置としてレストつき二腕鉤を設定，II： 間接支台装置としてレストのみを設定，III：間接支台装 置を設定せず

実験 2 : 間接支台装置のレストの設定位置を変化させた (被験者 B)

P 1：第一小臼歯に設定，P 2：第二小臼歯に設定， M 1：第一大臼歯に設定

実験 2 ：間接支台装置のレストの設定位置を変化させた (被験者 C)

P 1：第一小臼歯に設定，P 2：第二小臼歯に設定， M 2：第二大臼歯に設定

で決まる平面を義歯基準平面と規定して，この義歯基 準平面の動きを解析することによって，義歯全体の動 摇を分析する方法をとった。すなわち，義歯床後縁点 $(\mathrm{MPFP})$ ，直接支台装置のレスト $(\mathrm{PR}) ，$ 間接支台 装置のレスト（IR）に加えて，義歯基準平面上にお ける間接支台装置側の犬歯，第一・第二小臼歯，第 一・第二大兒歯相当部の 5 点 $(3,4,5 ， 6 ， 7)$ ，およ び直接支台装置のレストと義歯床後緑点を結ぶ直線上 において，直接支台装置のレストの前後 $5 \mathrm{~mm} に お け$ る点（PR+5および $\mathrm{PR}-5)$ を解析点として，それ ぞれの点の動摇を計測することとした。また，下顎運 動については下頡切歯点 (IC) を解析点とした（図 4).

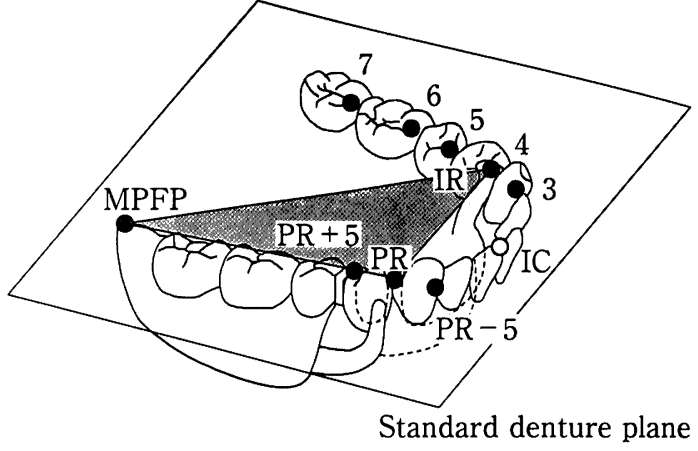

図 4 Measuring point for mandibular movement is the incisor point (IC)

The vertical displacements and measuring points are the primary rest (PR), the most posterior point in flange (MPFP), the tooth 5 points on the denture criteria plane $(3,4,5,6,7)$, the $5 \mathrm{~mm}$ anterior point from $\mathrm{PR}(\mathrm{PR}-5)$, and the $5 \mathrm{~mm}$ posterior point from $\mathrm{PR}(\mathrm{PR}+5)$

下顎運動と義歯の浮上解析点

MPFP, PR, IR の 3 点で定まる平面を義歯基準平面と 定義した

下顎運動の解析点：切歯点 (IC)

義歯の浮上解析点：直接支台装置レスト $(P R)$, 義歯床 後縁点 (MPFP), 義歯解析平面上における間接支台装 置側の歯列上の 5 点 $(3,4,5,6,7)$ および直接支台 装置のレストの前後 $5 \mathrm{~mm} に$ におる点 $(\mathrm{PR}-5, \mathrm{PR}+$ 5)

4）義歯の浮上量および下顎運動の測定方法 今回，義歯の上下方向の動摇，そのなかでも特に浮 上について分析することとし, 各義歯形態を相対的に 評価するため，浮上量を次のように定義した。

まず，下顎運動および義歯床後縁点の垂直成分の時 系列デー夕において，下顎運動の開口開始点から次の 開口開始点までを1 ストロークとし分割する。次に， 義歯床後縁点の義歯基準平面に対する垂直成分の最大 値を浮上量とした（図 5).

下顎運動については，下顎切歯点の義歯基準平面に 対する垂直成分を開口量として求めた（図 5).

なお，計測のベースラインは，咀嚼開始前の咬頭嵌 合位における各解析点の位置を基準とした。

\section{6. 統計処理}

各被験者について，義歯形態間における一元配置分 散分析の多重比較（Scheffé's comparison）を行っ た。 


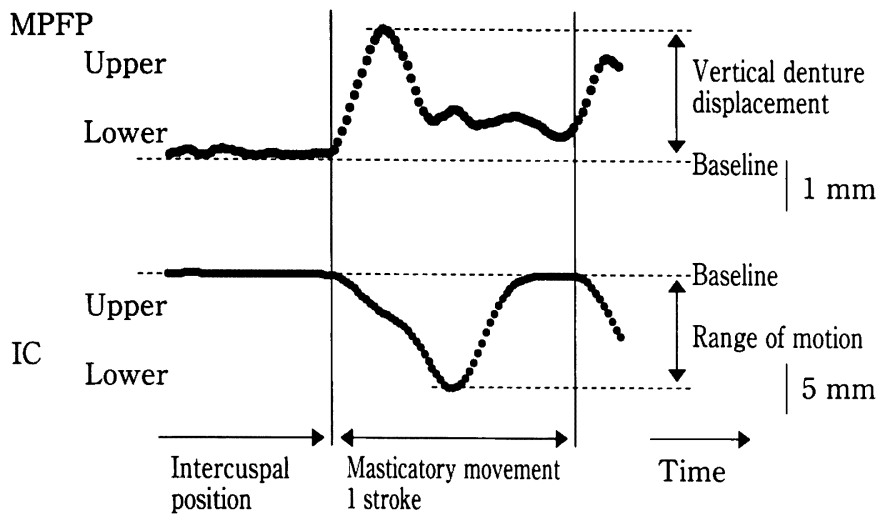

図 5 Method to measure the range of motion and the vertical displacement of MPFP

Each baseline is the position of IC and MPFP during intercuspal position

浮上量と開口量の測定方法

下顎運動の垂直成分より, 開口開始点から次の開口開始 点までを 1 ストロークに分割

開口量・浮上量：咬頭嵌合位の位置を Baseline とし，1 ストローク中の最大值を測定

\section{III. 結 果}

\section{1. 実験 1 について}

義歯床後縁点における浮上量の平均値は，直接支台 装置に RPI を用い，間接支台装置にレスト付二腕鉤 をもつ基本設計の形態 I では $1.9( \pm 0.7 ） \mathrm{~mm}$ ，間接 支台装置にレストのみをもつ形態 II では $2.0( \pm 0.6)$ $\mathrm{mm}$ と, 浮上量にほとんど変化は認められなかった。 しかし，間接支台装置のない形態IIIでは 3.4（土1.4） $\mathrm{mm}$ を示し, 形態 I・II の約 1.7 倍に増加した（図 $6)$.

\section{2. 実験 2 について}

被験者 Bにおいて，義歯床後縁点における浮上量の 平均値は，間接支台装置のレストが第一小臼歯に存在 する形態 P 1で1.4（土1.0） mm，レストが第二小臼 歯に存在する形態 P 2 では $1.7( \pm 0.9 ） \mathrm{~mm}$ ，レスト が第一大臼歯に存在する形態 M 1 では 2.1 ( \pm 1.6$)$ $\mathrm{mm}$ を示した. すなわち, 開口時の義歯の浮上量は, 形態 P 1 と比較して形態 P 2 では 1.2 倍, 形態 M 1 では 1.5 倍と, 間接支台装置のレストの設定位置が後 方に移動するに従って, 増加する結果となった（図 $6)$.

また被験者 Cにおいては，義歯床後縁点における浮

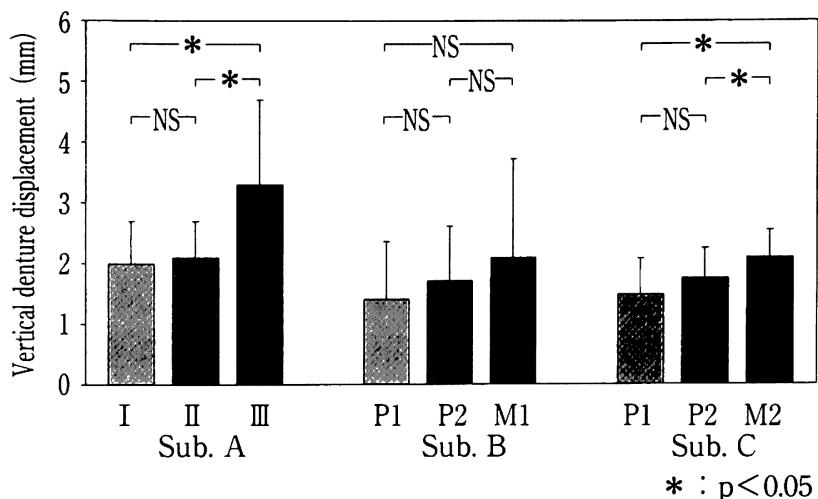

図 6 Maximum distance of MPFP in vertical component 義歯形態別の義歯床後緑点の浮上量

上量の平均值は，形態 P 1 で $1.5 （ \pm 0.6 ） \mathrm{~mm}$ ，形態 P 2では $1.7( \pm 0.4 ） \mathrm{~mm} ，$ レストが第二大臼歯に存 在する形態 M 2 では 2.1（土0.4） $\mathrm{mm}$ を示し, 形態 $\mathrm{P} 1$ と比較して形態 $\mathrm{P} 2$ では 1.1 倍, 形態 M 2 では 1.4 倍に増加して, 被験者 B と同様の傾向を示す結果 を得た（図6).

\section{IV. 考察}

1. 研究方法について

1）これまでの研究について

これまで下顎義歯の動摇は, 磁気抵抗素子を変位セ

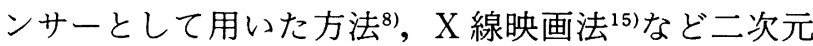
的な計測や，発光ダイオードを用いた三次元的な計 測" 代行われてきた．しかし，これらの研究では下顎 運動との同時記録がされていない.

また，これまでの研究は咬合時，すなわち静力学的 な状態における動摇が主な対象であった ${ }^{6 \sim 9)}$. 義歯に 加えた荷重により生じる義歯床の変化について, 支台 装置の種類によって義歯の変位量が異なること ${ }^{16)}$, 人 工歯の煩舌径を狭めることによって，義歯の変位量が

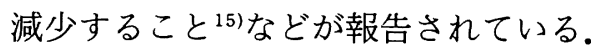

しかし，下顎運動の開口時や閉口時といった咬合時 以外，すなわち動力学的な状態において義歯がいかな る挙動を示しているのかについては，ほとんど報告さ れていない.

2）測定装置について

今回，測定に用いたTMJAWGRAPH ${ }^{\circledR}$ は，赤外 線反射光を利用した多標点運動測定装置である. 赤外 線反射光を用いる利点は，標点が小型，軽量であり， 
コード類を接続する必要がなく，しかも多数の標点の 同時測定が可能な点である.

現在使用されている主な 6 自由度顎運動測定装置の 口腔内に設置する装置の重量は，TRIMET ${ }^{\circledR}$ (東京歯 材社, 東京）のフェイスボウが $40 \mathrm{~g}^{17,18)}$, ナソヘキサ グラフ (小野測器, 神奈川) の下顎フェイスボウが $12 \mathrm{~g}^{19)}, \mathrm{MM}-\mathrm{J} 1^{\circledR}$ (松風, 京都) では総重量 $660 \mathrm{~g}$ で，下顎負担重量は約 $127 \mathrm{~g}^{20)}$ である。これに対し

て, 本研究で用いたマーカーは, 上顎用が $3 \mathrm{~g}$, 下顎 および義歯用が $2 \mathrm{~g}$ であり， 3 個の合計でも $7 \mathrm{~g}$ とき わめて軽量であり, 義歯の動摇および咀嚼運動にも影 響を与える可能性の最も少ない 6 自由度顎運動測定装 置といえる.

本システムの測定マーカーの位置分解能は, 前後方 向で $0.3 \mathrm{~mm}$ 以下，左右および上下方向では $0.2 \mathrm{~mm}$ 以下である．歯に荷重を加えた場合の変位量 ${ }^{21)}$ 義歯 床の粘膜への沈下量 ${ }^{22}$ から，義歯の挙動を定量的に扱 うには，0.1 mm 以下の測定精度が必要であるとする 考え ${ }^{23)}$ がある。かし，本研究では義歯の浮上とい う，動摇としては大きな現象について顎運動と同時測 定することを目的としているため，本システムは必要 な測定精度は得られていると考えられる。

\section{2. 間接支台装置の効果}

1）間接支台装置の形態による効果

実験 1 において, 間接支台装置が存在する形態 I ・ IIでは浮上量にほとんど違いが認められず，間接支台 装置の存在しない形態IIIで, 形態 I ・II と比較して約 1.7 倍と大きく増加した（図 6)。このことから, 義歯 床後縁の浮上量に対する, 間接支台装置のレストの有 効性が明らかとなった。

しかし，この結果から新たな疑問が生じた。

これまでの研究では，遊離端義歯において垂直的な 離脱力が働いた場合，歯列両側の最後方支台歯のもつ とも遠心のレストシートを通る仮想線を鉤間線とし, それを中心に回転するという考えや ${ }^{4,5,24,25)}$, 離脱力に 抵抗する直接支台装置と間接支台装置の維持腕におけ

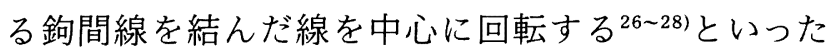
ように考えられてきた。

このような鉤間線法則に従えば，本症例では直接支 台装置と間接支台装置のレスト間に 1 本の鉤間線が想 定できる。この鉤間線上に義歯の浮上時の回転軸が存
在するとすれば, RPI クラスプの構造上 ${ }^{29,30)}$, 形態 I と II にられる義歯床後縁の浮上量に対する抵抗は, 間接支台装置の鉤腕によってもたらされると考えられ る.しかし，実験 1 により，間接支台装置の鉤腕を除 去した形態IIにおる浮上量は, 形態 I とほとんど違 いが認められなかった。このことは, 本症例におい て, 義歯床後縁の浮上に対する抑制効果は, 間接支台 装置の鉤腕によるものは小さく，間接支台装置の存在 によるものが大きいことを示している.

すなわち，義歯床後縁の浮上りに際して，これまで 考えられてきたような鉤間線による回転軸では理解し にくい結果となった。

つまり, 義歯床後縁の浮上量は, 回転軸そのものが 存在しない並進運動のみの浮上量なのか, 回転軸が銁 間線とは別の位置に存在する回転運動なのか, また は，この 2 つが複合したものなのかという考え方がで きる。

2）間接支台装置の設定位置による効果

そこで, 実験 2 において間接支台装置にレストのみ の形態を用いて, その設定位置を変化させ, 義歯床後 縁の浮上量に影響を及ぼすのか検討した.

その結果, 被験者 $\mathrm{B}, \mathrm{C}$ において開口時の義歯床後 縁点の浮上量は, 間接支台装置のレストを第一小臼歯 に設定した形態 P 1 と比較して, 第二小臼歯に設定し た形態 P 2 では 1.2 倍, 大臼歯に設定した形態では 1.5 倍と, 間接支台装置のレストの設定位置が後方に 移動するに従って，増加する結果となった（図 6).

これは, 先に述べた鉤間線が義歯床後縁の浮上時の 回転軸になっていることは疑わしい，という考えをさ らに強める結果となった。

\section{3. 義歯全体の動摇}

1) 並進運動と回転運動

義歯全体の動摇の様相を追及するため, 義歯床後縁 点, 直接支台装置のレスト, 間接支台装置のレストの 3 点を含む平面を義歯基準平面と定め, 開口時に伴う この平面の動きを分析することとした。

まず，直接支台装置のレストの位置での浮上量を算 出した。その結果, 被験者 B の形態 P 1, P 2, M 1 において，いずれも平均 $1.1 \mathrm{~mm}$ と同值を示した。ま た被験者 Cでは, 形態 $\mathrm{P} 1$ で平均 $1.1 \mathrm{~mm}$, 形態 $\mathrm{P} 2$ で平均 $1.0 \mathrm{~mm}$, 形態 $\mathrm{M} 2$ で平均 $1.1 \mathrm{~mm}$ とほほ同じ 


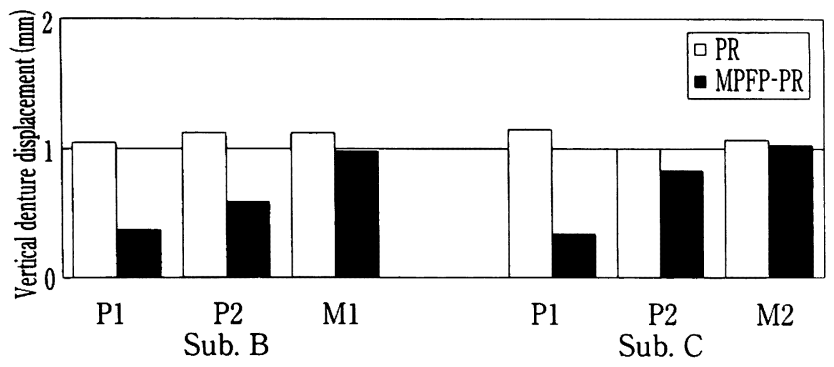

図 7 Maximum distance of $P R$ and MPFP-PR in vertical component (Sub. B, C)

被験者 $\mathrm{B}, \mathrm{C}$ における直接支台装置のレスト (PR) の 浮上量と, 義歯床後縁点と直接支台装置のレストの浮上 量の差 (MPFP-PR)

値を示した（図 7).この浮上量は，義歯床後縁点に おける浮上量の約 $0.5 \sim 0.7$ 倍を示しており，義歯は 義歯床後縁のみが浮上っているのではなく，直接支台 装置のレストも含めて, 全体として浮上しているとい う結果が示された。

しかしその一方で，直接支台装置のレストと義歯床 後縁点における浮上量には違いが認められ，その量は レストの設定位置が後方に移動するに従って増加した (図 7).すなわち，義歯の浮上り動摇は，義歯基準平 面の上方への並進運動による浮上と，義歯基準平面の 回転によって生じる浮上が複合したものであることが 明らかとなった。

2）浮上り回転軸と鉤間線の関係

義歯の回転により生じる動摇には, 回転軸が存在す るはずである．この回転軸を求めるためには，軸上の 2 点の定まることが必要である，そこで，欠損側の義 歯部における回転軸上の 1 点を求め, その点における 動摇を基準として，間接支台装置の存在する歯列上で の回転軸上のもう 1 点を検索することとした。

欠損側の義歯部における回転軸上の点として最も可 能性の高い直接支台装置のレストと，義歯基準平面上 におけるレストの前後 $5 \mathrm{~mm}$ の位置における浮上りを 比較した。その結果, 直接支台装置のレストを中心と して, 前後の点で符号が逆転しており, 久損側の回転 中心は，直接支台装置のレスト部にあると考えること に妥当性がある，次に，直接支台装置のレストの浮上 り量を基準として，義歯基準平面上における間接支台 装置側の 5 点 $(3,4,5,6,7)$ における浮上量を比 較することとした。

直接支台装置のレストが回転軸上の 1 点であること から，直接支台装置のレストと同じ浮上り量を示す
点, すなわち, 回転浮上量の值がゼロとなる点が, 回 転軸上のもう 1 点と定められる.

このようにして, 被験者 $\mathrm{B}, \mathrm{C}$ とも咀嚼ストローク ごとに算出した回転浮上量がゼロとなる点を求める と，3 から 7 までの広い範囲に存在した（図 8，9）。

この結果から, 被験者 Bにおいて, 浮上回転軸の 平均の位置は, 形態 P 1 では 4.5, 形態 $\mathrm{P} 2 \cdot \mathrm{M} 1$ で は 5 となった (図 8).

また, 被験者 Cでは, 浮上回転軸の平均の位置は, 形態 P 1・P 2 では 5 , 形態 M 2 では 6 となった（図 9).

すなわち, 被験者ごとに浮上り回転軸の存在位置は 異なったが，間接支台装置のレストの存在位置による 違いは明確でなく，ほぼ小臼歯部の一定の位置を示し た。

また, 被験者 $\mathrm{B}, \mathrm{C}$ の義歯において, 鉤間線と浮上 時の回転軸とは必ずしも一致していないことが明らか となった。

ここで改めて実験 2 における，義歯床後緑点の浮き 上がりについて考えてみると, 間接支台装置の設定位 置によって, 浮上回転軸と銁間線との位置関係に違い が認められる(図 10).

すなわち, 間接支台装置が浮上回転軸よりも歯列前 方に存在する場合には, 義歯の浮上時に間接支台装置 のレストには歯根方向の下向きに力が加わり, 義歯床 後緑の回転による浮上を抑制するように作用すると考 えられる. 逆に, 間接支台装置が浮上回転軸よりも歯 列後方に存在すると, 義歯の浮上り時に間接支台装置 のレストには歯冠方向の上向きに力が加わるため, 義 歯床後縁の回転による浮上を抑制できないと考えられ る.

\section{3. 義歯設計上の意義}

上述のごとく，下顎片側遊離端義歯において，義歯 の浮上時には回転軸が存在し, 間接支台装置の形態, およびその設定位置によって, 義歯床後縁の浮上に及 ほす抑制効果が違うことが明らかとなった．本症例に おいては, 浮上回転軸は小臼歯部に存在したことか ら，間接支台装置の設定位置を回転軸よりも前方の小 臼歯部, 犬歯部に設定することが, 義歯床後縁の浮上 を抑制するのに効果的であると考えられる。 

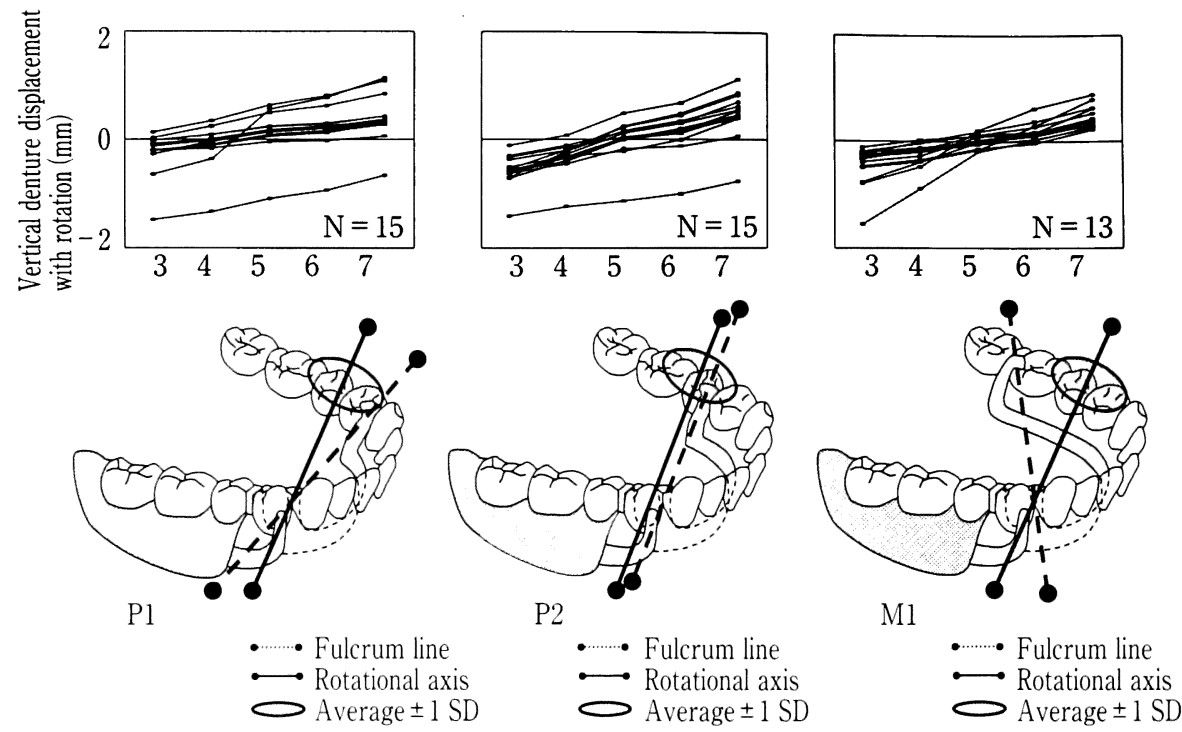

图 8 Vertical displacement with rotation movement at each denture design (Sub. B)

Comparison of the maximum distance of PR with the tooth 5 points on the denture criteria plane $(3,4,5,6,7)$ Comparison of the rotational axis with the fulcrum line

被験者 B の形態 P 1，P 2，M 1 における回転浮上量

直接支台装置のレストの浮上量から義歯基準平面上における間接支台装置側の 5 点（3，4，5，6，7）の浮上量を引 いたもの

被験者 B の形態 P 1，P 2，M 1 に扔ける銁間線と浮上回転軸の関係
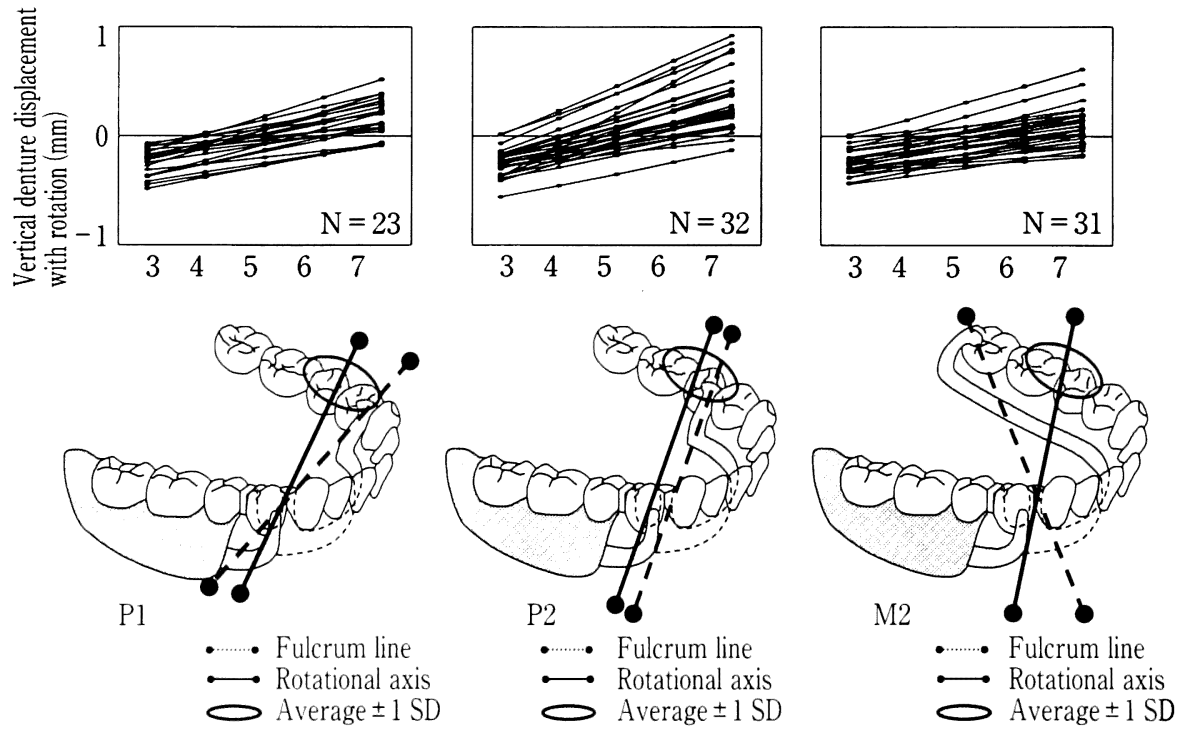

図 9 Vertical displacement with rotation movement at each denture design (Sub. C)

Comparison of the maximum distance of PR with the tooth 5 points on the denture criteria plane $(3,4,5,6,7)$ Comparison of the rotational axis with the fulcrum line 被験者 C の形態 P 1, P 2, M 2 における回転浮上量

直接支台装置のレストの浮上量から義歯基準平面上に㧍ける間接支台装置側の 5 点（3，4，5，6，7）の浮上量を引 いたもの

被験者 C の形態 P 1，P 2，M 2 における鉤間線と浮上回転軸の関係

\section{V. 結 論}

下顎片側遊離端義歯において，間接支台装置の形
態，およびその設定位置を変化させた状態での開口時 の浮上現象を追求し，以下の結論を得た。

1. 開口時における下顎片側遊離端義歯の浮上は, 義歯全体の上方への並進運動による浮上と，義歯の回 


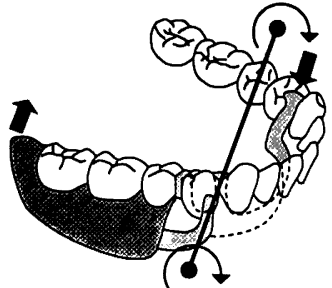

Rotational axis

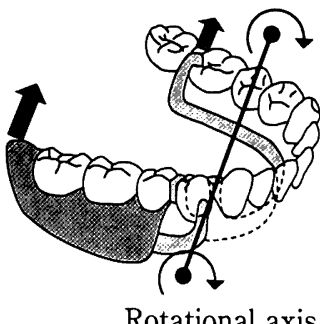

Rotational axis
図 10 Effect of indirect retainer position on vertical displacement

浮上回転軸と間接支台装置の位置関係による浮上の違 い

転によって生じる浮上が複合したものであることが明 らかとなった。

2. 義歯の回転による浮上の中心となっている回転 軸は，鉤間線とは関係なく，今回の片側遊離端義歯で は小臼歯部であった。しかし，欠損形態や，支台装置 形態などによって浮上時の回転軸は変化すると考えら れる.

3. 回転軸が一定の位置に存在したことから，間接 支台装置の設定位置によって，義歯床後縁の浮上に対 して抑制効果に違いがあることが明らかとなった。

\section{文献}

1）歯科保健医療研究会監修. 平成 11 年歯科保健関係統計 資料，東京：口腔保健協会, 1999.

2）金田 恒，土田幸弘，河野正司．咀嚼における片側遊離 端義菌装着の意義. 補綴誌 $43 ： 592-601,1999$.

3）河野正司，木戸寿明. 咀糫機能と咬合. 1. 咀嚊行動の 意味．補緅臨床 32：76-79, 1999.

4) 藍 稔. 小部分床義歯学 51-55, 東京：学建書院, 1986.

5）藍稔，五十嵐順正，平井敏博ほか。スタンダード部 分床義歯補緅学 71-88, 東京：学建書院, 1997.

6) Jüde HD. Untersuchungen über die Prothesenmechanik von partiellem Zahnersätz. Dtsch Zahnärztl Z 25:821-825, 1970.

7) Browning JD, Jameson WE, Stewert CD et al. Effect of positional loading of three removable partial denture clasp assemblies on movement of abutment teeth. J Prosthet Dent 55:347-351, 1986.

8）五十嵐順正. 部分床義歯の動摇解析 第 1 報 遊離端義 歯の動摇とその定量化について．補綴誌 $33: 369-375$, 1989.

9）西田 圭，小野高裕，野首孝祠. 下顎片側遊離端欠損症 例における垂直荷重時の義歯床の回転. 補緅誌 43 : 830-838, 1999.

10）土田幸弘，大竹博之，河野正司ほか. 赤外線反射光を利 用した多標点運動解析法の補綴学的応用の試み. 顎機能 誌 $5: 71-77,1998$.

11）大竹博之，河野正司. 下顎の機能運動時の下顎片側遊離
端義歯の浮き上がり。補綴誌 $43: 582-591,1999$.

12) Mongini F, Tempia-Valenta G, Benvegnu G. Computer-based assessment of habitual mastication. J Prosthet Dent 55:638-649, 1986.

13) Kang DW, Mongini F, Rossi $F$ et al. A system for the study of jaw movements. J Craniomandib Pract 11 : 63-68, 1993.

14）長谷川成男, 真柳昭紘. 6 自由度顎運動測定器のこと. 補綴誌 $42 ： 928-931 ， 1998$.

15）細見洋泰：下顎両側性遊離端義歯の人口歯形態が咀嚼時 の義歯動態におよぼす影響．補綴誌 $24 ： 284-300,1980$.

16）五十嵐順正, 河田守弘, 朝見光宏ほか. 維持歯と維持装 置の連結強度 第 1 報 各種クラスプの連結強度につい て. 補緅誌 $34: 1162-1169,1990$.

17）黒川昌彦，林 豊彦，宮川道夫ほか. 1 次元 CCD カメラ を用いた顎運動測定装置（JKN-1）の測定精度．信学 技報 MBE 92-96：81-88, 1992 .

18）河野正司. 6 自由度顎運動測定装置 TRIMETを使っ て. 補緅誌 $42: 913-920,1998$.

19）常盤 肇, 桑原洋助. 顎機能の臨床的診査 ナソヘキサ グラフを用いて。補緅誌 42：902-912, 1998.

20) 藤村哲也, 坂東永一. ディジタル方式顎運動測定器の開 発. 補緅誌 $35 ： 830-842,1991$.

21）五十嵐順正, 藍 稔, 斎藤良一. 非接触微小变位セン サーによる歯の動態観察 第 2 報 種々の観察例. 補綴 誌 $25: 295-303,1981$.

22）岸 正孝. 歯槽堤粘膜の被圧変位性に関する加圧面の面 積と変位量との関係についての実験的研究. 歯科学報 72 : 1043-1071, 1972.

23）加藤光雄, 笛木賢治, 羽毛田 匡ほか. 可撤性補経装置 の 3 次元的挙動 第 1 報 計測システムとその応用. 補 綴誌 $41: 719-728,1997$.

24）守川雅男. パーシャルデンチャーその考え方と臨床, 東 京：クインテッセンス出版, 1995.

25）芝 燁彦. 可撤性部分床義歯の臨床 74-76, 東京：医歯 薬出版, 1983.

26) Russell JS, Frank JW (芝 燁彦, 五十嵐順正). An Atlas of Removable Partial Denture Design（パーシャ ルデンチャー設計アルバム R.P.I. を中心に 122-125, 東 京：クインテッセンス出版, 1989), 1988.

27) Hubertus S, Horst G (三谷春保, 虫本栄子). Die Modellguß-Prothese (ワンピースキャストパーシャル 201-206, 東京：クインテッセンス出版, 1978), 1977.

28）三谷春保. 歯学生のパーシャルデンチャー 129-131, 東 京：医歯薬出版, 1979.

29) Kratochvil FJ. Influence of occlusal rest position and clasp design on movement of abutment teeth. J Prosth Dent $13: 114-124,1963$.

30) Krol AJ. RPI (rest, proximal plate, I bar) clasp retainer and its modifications. Dent Clin North Am $17: 631-649,1973$.

著者連絡先：湊修

于951-8514 新潟県新潟市学校町通 2-5274

TEL : 025-227-2891

FAX : 025-229-3454

E-mail : minato@dent.niigata-u.ac.jp 


\title{
Axis of Rotation Related to Vertical Displacement of a Lower Unilateral Distal Extension Removable Partial Denture
}

\author{
Minato Osamu and Kohno Shoji \\ Division of Removable Prosthodontics, Niigata University School of Medical and Dental Sciences \\ (Chief : Prof. Kohno Shoji)
}

J Jpn Prosthodont Soc $46: 655-664,2002$

\section{ABSTRACT}

Purpose : The purpose of this study was to analyze the effect of indirect retainers on the vertical displacement of lower unilateral distal extension removable partial dentures (U-RPD).

Methods : An available jaw tracking system (TMJAWGRAPH ${ }^{\circledR}$ ) was modified to measure the jaw movement and the motion of a removable partial denture, at the same time. Three markers were fixed in the U-RPD, mandible, and head, and allowed simultaneous 6 degree-of-freedom recording of their movements. The experimental denture could separate from direct retainers and indirect retainers. So, we could change denture form without changing occlusal contidion.

Results : 1 . The vertical denture displacement in the most posterior point in the flange (MPFP) was different with the design of indirect retainers. Without indirect retainer, vertical denture displacement increased. There was no relationship between range of motion and the vertical denture displacement. 2. The vertical denture displacement in MPFP was not influenced by the indirect retainer rest position. There was a relationship between the indirect retainer rest position and the vertical denture displacement.

Conclusions : The vertical denture displacement during mouth opening was able to classify, as a whole, upper movement and rotation movement. The rotational movement had an axis, which existed in direct retainer rest and in premolar. In this case, however, the axis had not related to the fulcrum line.

\section{Key words}

lower unilateral distal extension removable partial denture, vertical displacement, fulcrum line, rotational axis 